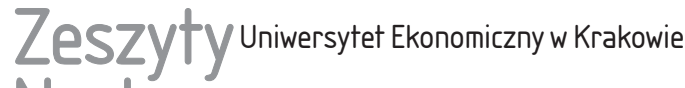 Naukowe
}

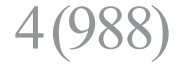

ISSN 1898-6447

e-ISSN 2545-3238

Zesz. Nauk. UEK, 2020; 4 (988): 25-43

https://doi.org/10.15678/ZNUEK.2020.0988.0402

Joanna Wielgórska-Leszczyńska

Justyna Beata Zakrzewska

\section{Wpływ wprowadzenia międzynarodowych standardów badania w Polsce na małe i średnie firmy audytorskie}

\section{Streszczenie}

Cel: Celem artykułu jest próba oceny wpływu obligatoryjnego stosowania międzynarodowych standardów badania (MSB) na rynek audytu w Polsce oraz na zakres procedur badania uproszczonych sprawozdań finansowych.

Metodyka badań: Do osiągnięcia celu wykorzystano w szczególności metodę analizy literatury przedmiotu, aktów prawnych wraz z uzasadnieniami oraz analizę wyników badań ankietowych i danych statystycznych.

Wyniki badań: Analiza danych statystycznych wykazała, że obligatoryjne wprowadzenie MSB w Polsce spowodowało zmniejszenie się liczby biegłych rewidentów pracujących w zawodzie oraz liczby firm audytorskich. Analiza wyników badań ankietowych wykazała natomiast, że zakres procedur badania uproszczonych sprawozdań finansowych nie uległ zmniejszeniu.

Joanna Wielgórska-Leszczyńska, Szkoła Główna Handlowa w Warszawie, Kolegium Zarządzania i Finansów, Instytut Rachunkowości, al. Niepodległości 162, 02-554 Warszawa, e-mail: jwielg@sgh.waw.pl, ORCID: https://orcid.org/0000-0002-3521-6325.

Justyna Beata Zakrzewska, Akademia Leona Koźmińskiego, ul. Jagiellońska 57/59, 03-301 Warszawa, e-mail: bzakrzewska@account-pl.eu, ORCID: https://orcid.org/0000-0003-4206-3125.

Artykuł udostępniany na licencji Creative Commons Uznanie autorstwa-Użycie niekomercyjne-Bez utworów zależnych 4.0 (CC BY-NC-ND 4.0); https://creativecommons.org/licenses/ by-nc-nd/4.0/ 
Wnioski: Na podstawie analizy wyników badań ankietowych stwierdzono, że wprowadzone uproszczenia w sprawozdawczości finansowej nie przekładają się na zmniejszenie zakresu procedur badania mimo skalowalności MSB.

Wkład w rozwój dyscypliny: Badania w zakresie wpływu MSB na badanie uproszczonych sprawozdań finansowych nie były dotychczas prowadzone. Pozwalają one na stwierdzenie, że zakres procedur badania w przypadku tych sprawozdań nie ulega zmniejszeniu oraz że badania ankietowe i analizy danych statystycznych są przydatne do oceny stosowanych uproszczeń i zmian na rynku audytu.

Słowa kluczowe: audyt, firma audytorska, rewizja finansowa, międzynarodowe standardy badania, międzynarodowe standardy rewizji finansowej i usług atestacyjnych, KSB, MSB, rynek audytu.

Klasyfikacja JEL: G32, M41, M42, M48.

\section{Wprowadzenie}

Globalny kryzys finansowy trwający od połowy 2007 r. do połowy 2009 r. przyczynił się do dużych zawirowań na giełdach papierów wartościowych, ujawniając jednocześnie braki w rzetelności prezentowanych informacji w sprawozdaniach finansowych (Piekarska 2008, s. 3).

Negatywne dla gospodarek światowych skutki kryzysu finansowego wpłynęły na podjęcie przez regulatorów wielu działań mających na celu poprawę jakości audytu, a tym samym poprawę jakości informacji ujawnianych w sprawozdaniach finansowych podmiotów gospodarczych (Kogut 2017, s. 86; Alwardat i Abdelhafid 2014, s. 86-98; Szczepankiewicz 2012a, s. 81-102; 2012b, s. 23-39; 2011a, s. 145; 2011b, s. 885-897; 2011c, s. 153-162). W 2010 r. Komisja Europejska, posiadająca inicjatywę legislacyjną w Unii Europejskiej i dysponująca odpowiednimi narzędziami do przygotowywania projektów regulacji prawnych UE, sprawująca nadzór nad realizacją polityk Unii i przestrzeganiem obowiązujących przepisów prawa oraz reprezentująca Unię Europejską na arenie międzynarodowej, opublikowała zieloną księgę dotyczącą ogólnych założeń oraz propozycji zmiany roli biegłego rewidenta w atestacji informacji finansowych (Komisja Europejska 2010, s. 5). Najistotniejsze zmiany dotyczyły (Komisja Europejska 2010, s. 6-9):

- uzyskania przez biegłego rewidenta wystarczającej, a nie absolutnej pewności, że sprawozdanie finansowe daje rzetelny i jasny obraz sytuacji jednostki,

- komunikacji biegłych rewidentów ze stronami zainteresowanymi poprzez jasne zdefiniowanie, jakie informacje i ustalenia biegły rewident powinien przedstawiać zainteresowanym stronom w ramach swojej opinii,

- nadzoru nad firmami audytorskimi, koncentracji rynku audytu oraz uproszczeń dla małych i średnich przedsiębiorstw i firm audytorskich. 
Efektem zapoczątkowanej w zielonej księdze dyskusji nad potrzebą zmian wzmacniających jakość badań sprawozdań finansowych w Unii Europejskiej było wprowadzenie dyrektywy Parlamentu Europejskiego i Rady nr 2014/56/UE oraz rozporządzenia Parlamentu Europejskiego i Rady (UE) nr 537/2014. Regulacje te obligowały państwa członkowskie Unii Europejskiej do implementacji zmian dotyczących rewizji finansowej do prawa lokalnego.

Do najistotniejszych zmian, jakie wprowadziła dyrektywa Parlamentu Europejskiego i Rady nr 2014/56/UE, należały:

- obowiązkowe przeprowadzanie wszystkich badań ustawowych w oparciu o międzynarodowe standardy badania (International Standards on Auditing),

- zobligowanie państw członkowskich do utworzenia publicznych systemów nadzoru nad biegłymi rewidentami i firmami audytorskimi.

Stosowanie jednolitych zasad rewizji finansowej we wszystkich krajach Unii Europejskiej miało na celu zapewnienie wysokiej jakości badań sprawozdań finansowych, a zmiany systemów nadzoru - wzmocnienie uprawnień do stosowania środków nadzorczych oraz do nakładania wysokich pieniężnych kar administracyjnych na biegłych rewidentów, firmy audytorskie i jednostki interesu publicznego w związku ze stwierdzonymi naruszeniami (np. do kwoty $1 \mathrm{mln}$ euro lub więcej w przypadku osób fizycznych oraz do określonej wartości procentowej całkowitych rocznych obrotów w poprzednim roku obrotowym w przypadku osób prawnych lub wszelkich innych jednostek) (Dyrektywa nr 2014/56/UE, par. 12, 14, 16).

Międzynarodowe standardy badania (MSB) zostały zaimplementowane do stosowania w Polsce uchwałą Krajowej Rady Biegłych Rewidentów nr 2783/52/2015 z dnia 10 lutego 2015 r. (KRBR 2015a).

Celem artykułu jest próba oceny wpływu wprowadzenia obligatoryjnego stosowania MSB na rynek audytu w Polsce oraz na zakres procedur badania uproszczonych sprawozdań finansowych. Do osiągnięcia celu wykorzystano w szczególności metodę analizy literatury przedmiotu oraz aktów prawnych wraz z uzasadnieniami, a w dalszej części metodę analizy wyników ankiety przeprowadzonej wśród biegłych rewidentów oraz analizę danych statystycznych. Poszukiwano odpowiedzi na następujące pytania badawcze:

- czy obligatoryjne wprowadzenie MSB w Polsce spowoduje istotne zmniejszenie się liczby biegłych rewidentów pracujących w zawodzie oraz liczby firm audytorskich?

- czy zakres procedur badania uproszczonych sprawozdań finansowych ulegnie zmniejszeniu? 


\section{Zmiany regulacji prawnych dotyczących audytu w Polsce}

Zmiany w strukturze właścicielskiej podmiotów gospodarczych spowodowane zmianami ustrojowymi na początku lat $90 . \mathrm{XX}$ w. polegały m.in. na osłabieniu roli Skarbu Państwa na rzecz własności prywatnej. Zapoczątkowały one zmiany w rachunkowości i rewizji finansowej w Polsce (Staszkiewicz 2017, s. 82). Aktem normującym sprawy rachunkowości jest ustawa o rachunkowości, która podlegała wielu modyfikacjom mającym na celu dostosowanie rozwiązań w rachunkowości do zmieniającej się gospodarki.

Pierwszym aktem prawnym regulującym usługi atestacyjne w Polsce była Ustawa z dnia 19 października 1991 r. o badaniu i ogłaszaniu sprawozdań finansowych oraz biegłych rewidentach i ich samorządzie. Na mocy ustawy powstał samorząd zawodowy biegłych rewidentów oraz podmiotów uprawnionych do badania sprawozdań finansowych (Fałowski 2020, s. 67). Regulacje te zostały zastąpione nowymi regulacjami wprowadzonymi Ustawą z dnia 13 października 1994 r. o biegłych rewidentach i ich samorządzie, które nie wprowadzały istotnych zmian w polskiej rewizji finansowej. Kolejna nowelizacja ustawy o biegłych rewidentach i ich samorządzie z dnia 21 września 2000 r. wprowadziła rejestr biegłych rewidentów i listę biegłych uprawnionych do badania sprawozdań finansowych. Zgodnie z zapisami nowej ustawy członkami samorządu zostali tylko biegli rewidenci. Został powołany nowy organ samorządu w postaci Krajowej Komisji Nadzoru, którego zadaniem było organizowanie i sprawowanie nadzoru oraz kontroli nad przestrzeganiem standardów wykonywania zawodu przez biegłych rewidentów i podmioty uprawnione do badania sprawozdań finansowych (Ustawa z dnia 21 września 2000 r. o biegłych rewidentach..., art. 28).

W wyniku kolejnej zmiany ustawy o biegłych rewidentach i ich samorządzie, podmiotach uprawnionych do badania sprawozdań finansowych oraz o nadzorze publicznym zmienił się system nadzoru nad firmami audytorskimi i biegłymi rewidentami. Celem utworzenia nowego organu, Komisji Nadzoru Audytowego, było sprawowanie nadzoru nad samorządem. Komisja Nadzoru Audytowego była instytucją w strukturze Ministerstwa Finansów (Ustawa z dnia 7 maja 2009 r. o biegłych rewidentach...). Na mocy przepisów tej ustawy podmioty uprawnione do badania sprawozdań finansowych podzielono na dwie grupy:

- wykonujące czynności rewizji finansowej zarówno w jednostkach zainteresowania publicznego (JZP), jak i w jednostkach niezaliczanych do JZP oraz

- wykonujące czynności rewizji finansowej tylko w jednostkach niezaliczanych do JZP.

Krajowe standardy rewizji finansowej (KSRF) w brzmieniu MSB, Międzynarodowych Standardów Usług Przeglądu (MSUP), Międzynarodowych Standardów Usług Atestacyjnych Innych niż Badania i Przeglądy Historycznych Informacji 
Finansowych (MSUA), a także Przedmowa do międzynarodowych standardów i innych dokumentów dotyczących kontroli jakości, badań, przeglądów, innych usług atestacyjnych i usług pokrewnych oraz Międzynarodowe założenia koncepcyjne usług atestacyjnych wydane przez Radę Międzynarodowych Standardów Rewizji Finansowej i Usług Atestacyjnych (IAASB) zostały przyjęte uchwałą nr 2783/52/2015 z dnia 10 lutego 2015 r. przez Krajową Radę Biegłych Rewidentów (KRBR 2015a).

Międzynarodowe standardy rewizji finansowej stały się regulacjami krajowymi i musiały być obligatoryjnie stosowane przez podmioty uprawnione do badań sprawozdań finansowych (KRBR 2015a):

1) wykonujące badania rocznych sprawozdań finansowych lub przeglądy sprawozdań finansowych $\mathrm{JZP}^{1}$ sporządzonych za okresy kończące się 31 grudnia 2016 r. i później,

2) wykonujące badania rocznych sprawozdań finansowych lub przeglądów sprawozdań finansowych jednostek niebędących JZP sporządzonych za okresy kończące się 31 grudnia 2017 r. i później,

3) wykonujące usługi atestacyjne inne niż badania i przeglądy historycznych informacji finansowych rozpoczęte po 1 stycznia 2017 r. i później.

Istotne zmiany $\mathrm{w}$ zakresie systemu kontroli wewnętrznej zostały również wprowadzone uchwałą Krajowej Rady Biegłych Rewidentów nr 2784/52/2015 z dnia 10 lutego 2015 r. (KRBR 2015b). Podmioty uprawnione wykonujące badania rocznych sprawozdań finansowych lub przeglądy sprawozdań finansowych JZP sporządzonych za okresy kończące się między 31 grudnia 2016 r. a 31 grudnia 2017 r. miały obowiązek ustanowienia i stosowania kontroli jakości podmiotu uprawnionego zgodnie z zasadami wynikającymi z międzynarodowych standardów kontroli jakości (MSKJ) od 1 stycznia 2016 r., a pozostałe podmioty uprawnione od 1 stycznia 2017 r. Podmioty uprawnione mogły stosować MSB wcześniej, pod warunkiem wprowadzenia nowych zasad kontroli wewnętrznej (MSKJ 1) i poinformowania o tym Krajowej Komisji Nadzoru.

Największą zmianą w metodologii przeprowadzania badania sprawozdania finansowego według MSB było podejście do badania sprawozdania finansowego w oparciu o oszacowanie ryzyka istotnego zniekształcenia - biegły rewident powinien znaleźć odpowiedź na pytanie, jakie czynniki ryzyka wynikające z prowadzonej działalności gospodarczej mogłyby spowodować istotne zniekształcenie w badanym sprawozdaniu finansowym. Identyfikacja i oszacowanie ryzyka istotnego zniekształcenia są możliwe jedynie poprzez poznanie jednostki i jej otoczenia gospodarczego.

${ }^{1}$ Definicja JZP zawarta jest w art. 2 pkt 9 Ustawy z dnia 11 maja 2017 r. o biegłych rewidentach, firmach audytorskich oraz nadzorze publicznym (Dz.U. poz. 1089 z późn. zm.). 
MSB obligują biegłego rewidenta, aby na etapie oszacowania ryzyka istotnego zniekształcenia zastosował procedury badania identyfikujące procesy kontroli wewnętrznej w jednostce istotne dla sprawozdawczości finansowej oraz ocenił ich adekwatność do zabezpieczenia przed zidentyfikowanymi i oszacowanymi czynnikami ryzyka istotnego zniekształcenia. Wiedza o jednostce, jej otoczeniu prawno-gospodarczym wraz z kontrolą wewnętrzną zapewnia biegłemu rewidentowi punkt odniesienia do wydawania sądów dotyczących szacowania ryzyka i stanowi bazę do opracowania planu badania będącego odpowiedzią na oszacowane ryzyko istotnej nieprawidłowości w sprawozdaniu finansowym. Pozwala to również na wyznaczenie poziomów istotności, ocenę prawidłowości wyboru i zastosowanie zasad (polityki) rachunkowości przez kierownictwo, ocenę prawidłowości i kompletności ujawnień sprawozdania finansowego, zidentyfikowanie pozycji sprawozdania finansowego wymagających szczególnej uwagi (np. transakcje z podmiotami powiązanymi, nietypowe lub złożone ustalenia umowne, zasadność kontynuacji działalności lub niecodzienne transakcje), czy też zaplanowanie dalszych procedur badania w celu ograniczenia ryzyka badania do niskiego, możliwego do zaakceptowania poziomu (Przewodnik... 2013, s. 51-53).

Istotna rewolucja na rynku firm audytorskich w Polsce nastąpiła w 2017 r. w wyniku kolejnej zmiany ustawy o biegłych rewidentach, firmach audytorskich oraz nadzorze publicznym. Ustawa zaczęła obowiązywać od 21 czerwca 2017 r., a firmy audytorskie miały tylko cztery miesiące na dostosowanie się do nowych regulacji. Wyjątkiem były nowe zasady opłat z tytułu nadzoru, które weszły w życie od 1 stycznia 2018 r. (Ustawa z dnia 11 maja 2017 r. o biegłych rewidentach...). Na mocy ustawy przepisy dotyczące badania sprawozdań finansowych znajdujące się w ustawie o rachunkowości zostały przeniesione do ustawy o biegłych rewidentach, firmach audytorskich oraz nadzorze publicznym, a opinia i raport z badania sprawozdania finansowego zostały zastąpione, zgodnie z krajowymi standardami rewizji finansowej w brzmieniu MSB, sprawozdaniem $\mathrm{z}$ badania. Wszystkie firmy audytorskie uchwałą Krajowej Rady Biegłych Rewidentów nr 913/22a/2017 z dnia 24 stycznia 2017 r. zostały zobligowane do stosowania KSRF w brzmieniu MSB (KRBR 2017).

Ostatnia zmiana ustawy o biegłych rewidentach miała miejsca w 2019 r. Jedną z najważniejszych zmian było wprowadzenie nadzoru publicznego sprawowanego przez Polską Agencję Nadzoru Audytowego nad działalnością (Ustawa z dnia 19 lipca 2019 r. o zmianie ustawy o biegłych rewidentach...):

- firm audytorskich,

- Polskiej Izby Biegłych Rewidentów, w tym w zakresie wpisu do rejestru biegłych rewidentów,

- firm audytorskich zatwierdzonych w innym niż Rzeczpospolita Polska państwie UE i wpisanych na listę na podstawie art. 58, w zakresie przewidzianym ustawą, 
- jednostek audytorskich pochodzących z państwa trzeciego i wpisanych na listę tych firm audytorskich, w zakresie przewidzianym ustawą w Polsce.

\section{Polski rynek audytu w liczbach}

Biegli rewidenci, mimo wielu akcji edukacyjnych i programów szkoleniowych mających na celu pomoc w dostosowaniu do nowych standardów wykonywania zawodu i kolejnych zmian ustawy o biegłych rewidentach, rezygnowali z czynnego wykonywania zawodu, co zaprezentowano na rys. 1. Liczba zarejestrowanych biegłych rewidentów od 1 stycznia 2017 r. do końca grudnia 2019 r. spadła o 861 osób i wynosiła 3623 osoby, z czego ok. 33\% pracowało w sieciach największych firm audytorskich przeprowadzających badania ustawowe JZP (KNA 2019, s. 14). Na uwagę zasługuje fakt, że bilans skreśleń z rejestru i wpisów do rejestru jest w analizowanym okresie ujemny (zob. tabela 1). Według danych Komisji Nadzoru Audytowego (KNA 2019, s. 11) tendencja spadkowa liczby biegłych rewidentów wykonujących zawód (spadek o 11\%) i niewykonujących zawodu (spadek o 19\%) trwa od 2010 r. (KNA 2019, s. 14-16), jednak największy spadek liczby biegłych rewidentów utrzymuje się od 2017 r. (zob. rys. 1). Główne przyczyny takiej sytuacji to m.in.:

- obligatoryjne stosowanie KSB w brzmieniu MSB,

- zmniejszający się rynek obligatoryjnych badań sprawozdań finansowych,

- wysokie kary finansowe nieadekwatne do zidentyfikowanych nieprawidłowości,

- ustanowienie statusu biegłego rewidenta seniora, pozwalającego tylko na zachowanie tytułu bez prawa wykonywania czynności rewizji finansowej²

Jak przedstawiono na rys. 2, w analizowanym okresie na rynku usług audytorskich odnotowano także spadek liczby firm audytorskich o 165 jednostek. Również i w tym przypadku liczba skreśleń była wyższa niż liczba wpisów nowych firm (zob. tabela 2). Znaczny spadek liczby biegłych rewidentów i firm audytorskich może mieć wpływ na koncentrację na rynku usług audytorskich. Według danych opublikowanych przez Komisję Nadzoru Audytowego (KNA 2019, s. 12) największy spadek dotyczy liczby firm audytorskich prowadzonych w formie jednoosobowej działalności gospodarczej oraz małych firm audytorskich prowadzonych w różnych formach prawnych, co można powiązać ze

${ }^{2}$ Zgodnie z art. 19 Ustawy z dnia 11 maja 2017 r. o biegłych rewidentach, firmach audytorskich oraz nadzorze publicznym (Dz.U. 2017, poz. 1089), biegły rewident, który osiągnął wiek emerytalny i na swój wniosek wystąpił z samorządu biegłych rewidentów, może posługiwać się tytułem „biegły rewident senior”. Biegły rewident senior nie jest wpisany do rejestru biegłych rewidentów i nie może wykonywać czynności rewizji finansowej zastrzeżonych dla biegłych rewidentów. 
spadkiem liczby biegłych rewidentów wpisanych do rejestru (rys. 2). Podobnie jak w przypadku biegłych rewidentów, na zmniejszenie liczby firm audytorskich miały wpływ restrykcyjne regulacje prawne, wysokie kary finansowe oraz rosnące koszty prowadzenia działalności (np. rozszerzone wymogi dokumentacyjne, koszty szkoleń, zwiększone opłaty z tytułu nadzoru³).

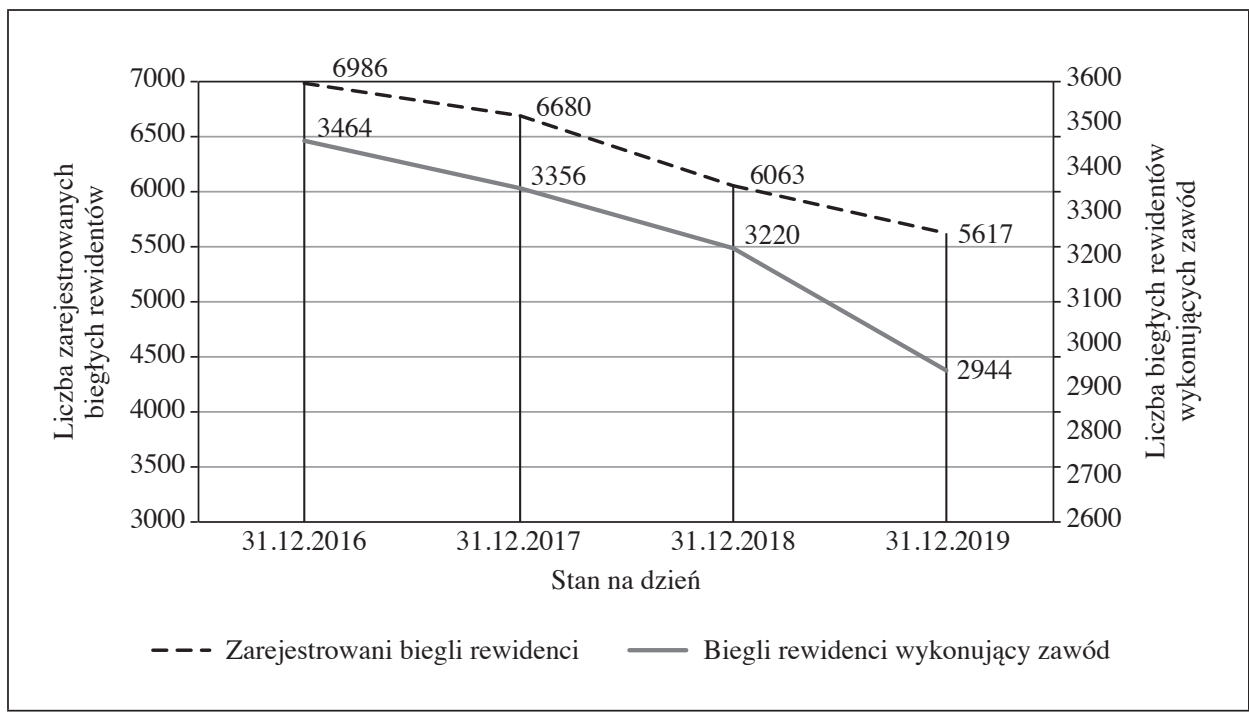

Rys. 1. Liczba zarejestrowanych i wykonujących zawód biegłych rewidentów w Polsce Źródło: opracowanie własne na podstawie danych otrzymanych z Polskiej Izby Biegłych Rewidentów i Polskiej Agencji Nadzoru Audytowego.

Tabela 1. Liczba biegłych rewidentów w Polsce w latach 2016-2019

\begin{tabular}{|l|c|c|c|c|}
\hline \multirow{2}{*}{\multicolumn{1}{|c|}{ Wyszczególnienie }} & \multicolumn{4}{|c|}{ Stan na dzień } \\
\cline { 2 - 5 } & 31.12 .2016 & 31.12 .2017 & 31.12 .2018 & 31.12 .2019 \\
\hline Zarejestrowani biegli rewidenci & 6986 & 6680 & 6063 & 5617 \\
\hline Liczba skreśleń w roku & 238 & 462 & 719 & 585 \\
\hline Liczba wpisów w roku & 139 & 156 & 102 & 141 \\
\hline Bilans wpisów i skreśleń & -99 & -306 & -617 & -444 \\
\hline $\begin{array}{l}\text { Biegli rewidenci wykonujący } \\
\text { zawód }\end{array}$ & 3464 & 3356 & 3220 & 2944 \\
\hline
\end{tabular}

Źródło: opracowanie własne.

${ }^{3}$ Od 1 stycznia 2020 r. opłata z tytułu nadzoru pobierana jest od wszystkich usług atestacyjnych. Do 31 grudnia 2019 r. opłata była pobierana wyłącznie od badania sprawozdań finansowych. 


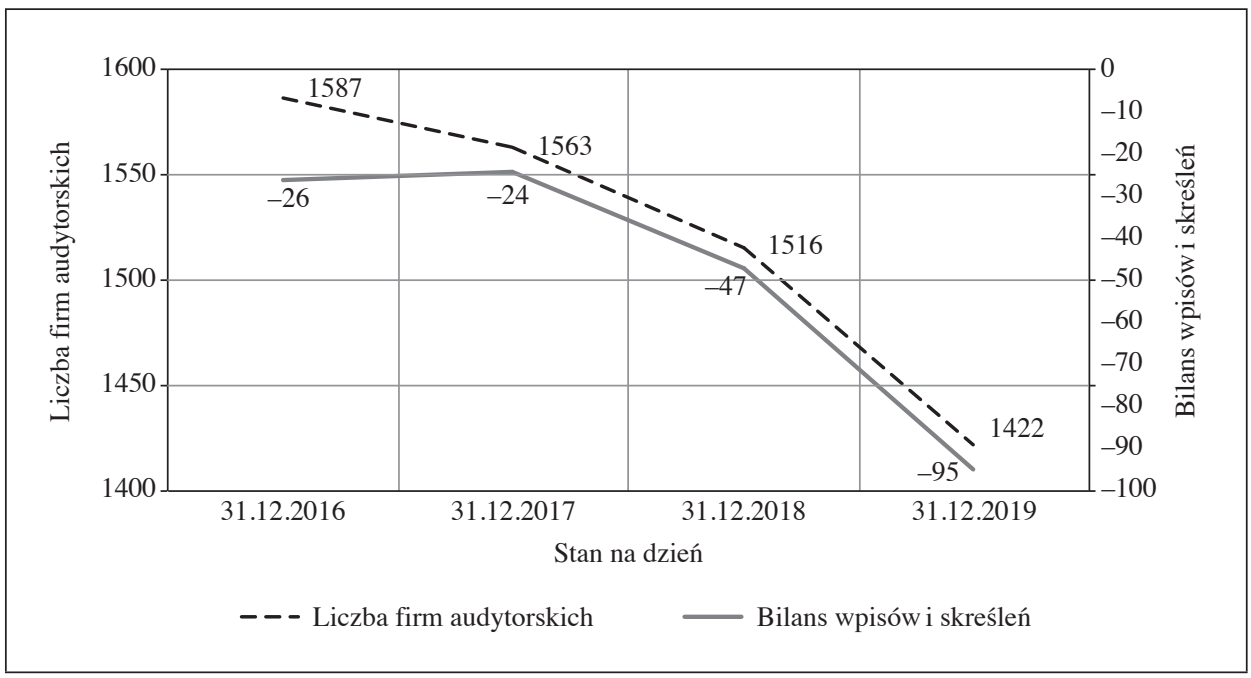

Rys. 2. Liczba firm audytorskich oraz bilans wpisów i skreśleń w Polsce w latach 2016-2019

Źródło: opracowanie własne na podstawie danych otrzymanych z Polskiej Izby Biegłych Rewidentów i Polskiej Agencji Nadzoru Audytowego.

Tabela 2. Firmy audytorskie w Polsce w latach 2016-2019

\begin{tabular}{|l|c|c|c|c|}
\hline \multirow{2}{*}{\multicolumn{1}{c|}{ Wyszczególnienie }} & \multicolumn{4}{c|}{ Stan na dzień } \\
\cline { 2 - 5 } & 31.12 .2016 & 31.12 .2017 & 31.12 .2018 & 31.12 .2019 \\
\hline Liczba firm audytorskich & 1587 & 1563 & 1516 & 1422 \\
\hline Liczba skreśleń w roku & 89 & 96 & 86 & 149 \\
\hline Liczba wpisów w roku & 63 & 72 & 39 & 54 \\
\hline Bilans wpisów i skreśleń & -26 & -24 & -47 & -95 \\
\hline
\end{tabular}

Źródło: opracowanie własne.

Jak wskazuje J. Gad (2018, s. 12), koncentracja na rynku usług audytorskich skutkuje m.in. ograniczonymi możliwościami wyboru firmy audytorskiej, wzmacniając pozycję rynkową największych firm audytorskich, oraz zmniejsza motywację do poprawy jakości audytu. Według danych Komisji Nadzoru Audytowego (KNA 2019, s. 4) w 2018 r. jedynie 74 firmy audytorskie przeprowadzały badania ustawowe sprawozdań finansowych JZP, czyli tylko 5\% wszystkich firm audytorskich. Firmy te pod względem przychodów z tytułu rewizji finansowej stanowią ok. 70\% rynku rewizji finansowej. Na rynku badań ustawowych sprawozdań finansowych JZP dominują firmy z tzw. wielkiej czwórki (Deloitte, E\&Y, KPMG, PwC), które łącznie osiągnęły $74,8 \%$ przychodów z badań ustawowych na rzecz JZP w Polsce 
w 2018 r. Według danych zaprezentowanych w raporcie World Bank Group (Rynek audytu... 2016, s. 9) liczba firm audytorskich badających JZP uległa zmniejszeniu. W 2013 r. było ich 155, w 2014 r. ich liczba spadła do 127, a w 2015 r. wynosiła 123. Należy zwrócić uwagę, że w ciągu pięciu lat rynek firm audytorskich badających JZP uległ zmniejszeniu o 48\%. Również Komisja Europejska (2017, s. 8) zauważa, że w krajach Unii Europejskiej nastąpiło zdominowanie rynku badań ustawowych sprawozdań finansowych JZP przez firmy należące do wielkiej czwórki. Dane uzyskane z 28 państw członkowskich wskazują, że udział wielkiej czwórki w rynku badania sprawozdań finansowych jednostek interesu publicznego wynosił prawie $70 \%$ w 2015 r. Opierając się na danych dotyczących 21 państw członkowskich, wskazuje się, że pod względem obrotów koncentracja rynku w tym okresie wynosiła średnio ok. 80\%. Według danych Komisji Europejskiej (2017, s. 8) wielka czwórka posiadała koncentrację na poziomie oligopolu pod względem liczby badań ustawowych w 11 państwach członkowskich, a w 15 państwach członkowskich - pod względem obrotów. Zdaniem Komisji Europejskiej (2017, s. 15) rynek badań ustawowych jednostek interesu publicznego wykazuje stosunkowo wysoką koncentrację w większości państw członkowskich, zwłaszcza w zakresie obrotów. Zmiany regulacji na poziomie unijnym (dyrektywy Parlamentu Europejskiego i Rady nr 2013/34/UE i nr 2014/56/UE oraz rozporządzenie Parlamentu Europejskiego i Rady (UE) nr 537/2014) dotyczące obowiązkowej rotacji firm audytorskich i biegłych rewidentów oraz nowych obowiązków komitetów audytu związanych z wyborem firmy audytorskiej miały na celu wzmocnienie niezależności i obiektywizmu biegłych rewidentów i firm audytorskich. Według Ministerstwa Finansów (http://www.mf.gov.pl/ministerstwo-finansow/dzialalnosc/rewizja-finansowa/aktualności, data dostępu: 17.02.2020) działania te wpłyną na ograniczenie przewagi konkurencyjnej dużych firm sieciowych, a otwarcie możliwości wejścia na rynek innym podmiotom spowoduje dekoncentrację rynku badań ustawowych JZP.

Jak podaje K. Kucharczyk (2018), ok. 160 podmiotów musiało zmienić audytora do badania sprawozdań finansowych za 2018 r. na skutek wprowadzenia nowych wymogów rotacji firm audytorskich i biegłych rewidentów. Jak twierdzi P. Zaczyński (Kucharczyk 2018), zmiany te nie uderzyły istotnie w liderów rynku audytu w Polsce, ponieważ w przypadku konieczności zmiany audytora duzi klienci najczęściej przechodzili do innej firmy audytorskiej będącej liderem na rynku, co nie miało miejsca w przypadku najmniejszych firm audytorskich.

Celem ujednolicenia podejścia do badania ustawowego w oparciu o MSB było zapewnienie wysokiej jakość wszystkich badań ustawowych wymaganych przez prawo. Dodatkowym efektem wprowadzonych zmian okazała się koncentracja na rynku audytu w Polsce. J. Gad (2018, s. 12) twierdzi, z czym należy się zgodzić, że wysoka koncentracja na rynku audytorskim związana jest ze znacznymi barierami wejścia nowych podmiotów na ten rynek, do których można m.in. zaliczyć: 
- brak możliwości finansowych i technicznych przeprowadzania zlecenia w określonym czasie i w miejscach prowadzenia działalności klienta,

- brak specjalistycznej wiedzy dotyczącej działalności gospodarczej prowadzonej przez potencjalnego klienta,

- brak wypracowanej marki na rynku.

Taką sytuację można zaobserwować również na polskim rynku audytu, gdzie bariery te spowodowały istotny spadek liczby firm audytorskich oraz biegłych rewidentów czynnie wykonujących zawód, co zostało zaprezentowane na rys. 1 i 2.

Należy zwrócić uwagę, że zdaniem J.D. Eshlemana i B.P. Lawsona (2017, s. 81) koncentracja na rynku usług audytorskich może być związana z ekonomią skali oraz bardzo dużą konkurencją wśród pozostałych dostawców usług audytorskich, która powinna skutkować obniżeniem opłat związanych z badaniem sprawozdań finansowych. Na polskim rynku firm audytorskich sytuacja taka nie miała jednak miejsca. Według danych opublikowanych przez Komisję Nadzoru Audytowego (KNA 2019, s. 12) w okresie od 2010 do 2015 r. zmniejszyła się łączna kwota przychodów osiąganych przez firmy audytorskie z tytułu rewizji finansowej, co było spowodowane m.in. spowolnieniem gospodarczym w Polsce będącym pochodną kryzysu mającego początki w 2008 r. w USA, ale już od 2015 r. następuje wzrost przychodów firm audytorskich z tytułu rewizji finansowej mimo spadku ich liczby na rynku. Przychody firm audytorskich badających JZP w latach 2015-2018 również uległy zwiększeniu - z $506 \mathrm{mln}$ zł do $531 \mathrm{mln}$ zł - mimo zmniejszenia się ich liczby o $48 \%$.

\section{Wpływ MSB na badanie uproszczonych sprawozdań finansowych}

Istnieje wiele definicji małych i średnich jednostek. Definicje te różnią się między sobą, a ich brzmienie zależy od regulacji prawnych, których dotyczą. Inną definicję małych i średnich jednostek znajdziemy w ustawie Prawo przedsiębiorców, inną w ustawie o rachunkowości, a jeszcze inną w ustawach podatkowych. Najczęstszymi kryteriami podziału są wielkość przychodów, zatrudnienie czy wielkość aktywów. Inne kryteria podziału jednostek są zaprezentowane w MSB. Zgodnie z nimi „mniejszą jednostką” jest jednostka posiadająca następujące cechy (Krajowy Standard Badania 200, par. A66):

1) skoncentrowanie praw własności i zarządzania w rękach małej grupy osób (często jednej osoby - będącej osobą fizyczną lub inną osobą prowadzącą działalność gospodarczą pod warunkiem, że właściciel wykazuje odpowiednie cechy jakościowe) oraz 
2) jedną lub więcej z poniższych cech:

a) proste lub niezłożone transakcje,

b) prosta ewidencja księgowa,

c) niewiele gałęzi działalności oraz niewiele produktów w ramach linii,

d) nieliczne kontrole wewnętrzne,

e) nieliczne szczeble kierownictwa odpowiedzialnego za szeroki zakres kontroli lub

f) nieliczny personel o rozległych obowiązkach.

Należy pamiętać, że zgodnie z KSB 200 wykaz cech jakościowych nie jest wyczerpujący i nie dotyczy wyłącznie mniejszych jednostek, a mniejsze jednostki nie muszą wykazywać wszystkich tych cech, ponadto rozważania szczególne dotyczące mniejszych jednostek zawarte w MSB opracowano głównie z myślą o jednostkach nienotowanych na giełdzie. Należy mieć jednak na uwadze, że niektóre z rozważań mogą być pomocne podczas badania mniejszych jednostek notowanych na regulowanych rynkach ${ }^{4}$.

Biegły rewident badający sprawozdanie finansowe jednostki posiadającej ww. cechy może skorzystać ze skalowalności MSB w badaniu małych i średnich jednostek przy jednoczesnym wysokim poziomie jakości wykonywania zlecenia badania sprawozdania finansowego. W ramach skalowalności, czyli proporcjonalnego podejścia do badania sprawozdań finansowych, charakter, zakres i dokumentacja badania są określane jako funkcja wielkości, złożoności i ryzyka związanego z działalnością jednostki, której sprawozdanie finansowe podlega badaniu. Na uwagę zasługuje fakt, że jakość badania oraz rzetelność opinii biegłego rewidenta muszą być takie same dla wszystkich badanych sprawozdań finansowych. Proporcjonalne zastosowanie MSB w badaniu sprawozdania finansowego polega na (Rada dyrektorów... 2015):

1) stwierdzeniu braku przesłanek do zastosowania danego standardu w badaniu sprawozdania finansowego; jeśli zagadnienia wymienione $\mathrm{w}$ standardzie nie występują w badaniu sprawozdania finansowego danej jednostki, to dany standard nie ma zastosowania w całości (Krajowy Standard Badania 200, par. 22);

2) stwierdzeniu braku przesłanek do zastosowania konkretnego szczegółowego wymogu standardu. Sytuacja taka może wystąpić, jeśli biegły rewident przestrzega każdego wymogu standardu, ale jeśli wymóg nie jest odpowiedni, ponieważ ma

${ }^{4}$ Zgodnie z art. 14 ust. 1 Ustawy z dnia 29 lipca 2005 r. o obrocie instrumentami finansowymi, rynkiem regulowanym jest działający w sposób stały wielostronny system zawierania transakcji, których przedmiotem są instrumenty finansowe dopuszczone do obrotu w tym systemie, zapewniający inwestorom powszechny i równy dostęp do informacji rynkowej w tym samym czasie przy kojarzeniu ofert nabycia i zbycia instrumentów finansowych oraz jednakowe warunki nabywania i zbywania tych instrumentów, zorganizowany i podlegający nadzorowi właściwego organu na zasadach określonych w przepisach ustawy, jak również uznany przez państwo członkowskie za spełniający te warunki i wskazany Komisji Europejskiej jako rynek regulowany (tekst jednolity Dz.U. 2020, poz. 89). 
charakter warunkowy, a warunek nie zachodzi, to daje to możliwość odstąpienia od stosowania poszczególnych zasad warunkowych. Przykładem są wymogi dotyczące treści opinii z zastrzeżeniem. Jeśli taka opinia nie będzie sporządzana, to wymogi te nie są przez biegłego rewidenta stosowane. Dodatkowe wytyczne na temat warunkowego odstąpienia od stosowania wymogów standardów można znaleźć w KSB w części „Zastosowania i inne materiały objaśniające”;

3) zastosowaniu ogólnych (,skalowalnych") wymogów standardu MSB, zawierających wiele stwierdzeń dotyczących przeprowadzania badania, w których w sposób ogólny uwzględniona jest kwestia proporcjonalności (skalowania) standardów badania. Przykładem mogą być zapisy standardu KSB 230, uzależniające formę, zawartość i zakres dokumentacji badania m.in. od wielkości i złożoności badanej jednostki, czy KSB 300, określającego, że forma, zawartość i zakres dokumentacji badania zależą od wielkość i złożoność jednostki;

4) zastosowaniu konkretnych wskazówek zawartych w sekcjach „Zastosowania i inne materiały objaśniające” MSB, zawierających wskazówki i wytyczne mające zastosowanie w badaniu mniejszych jednostek.

Obligatoryjne stosowanie nowych standardów wykonywania zawodu i nowych wymogów ustawowych nakłada na firmy audytorskie dodatkowe obowiązki $\mathrm{i}$ istotnie wpływa na proces badania sprawozdania finansowego.

Ostatnie publikacje dotyczące rynku firm audytorskich, takie jak (Iwanowicz (2019, KNA 2019, Gad 2018, Komisja Europejska 2017) zawierają analizę przepisów prawa i literatury oraz analizę informacji pochodzących ze sprawozdań finansowych JZP, w tym notowanych na giełdach papierów wartościowych. Rynek firm audytorskich nie składa się jednak wyłącznie z firm audytorskich badających JZP, ale również z firm niebadających tych jednostek. Dlatego podjęto próbę analizy, jak wygląda sytuacja w przypadku badania jednostek sporządzających uproszczone sprawozdania finansowe. W tym celu przeprowadzono badania ankietowe, których celem było sprawdzenie wpływu stosowania MSB na proces badania uproszczonych sprawozdań finansowych. Badanie ankietowe przeprowadzono w 2018 r. na próbie 550 biegłych rewidentów wybranych w sposób losowy (w losowaniu prostym niezależnym) spośród uczestników obligatoryjnych szkoleńzawodowych. Otrzymano zwrotnie ankiety od 345 biegłych rewidentów $(62,73 \%)$. $\mathrm{Z}$ analizy wyłączono 35 respondentów, którzy nie udzielili odpowiedzi na ani jedno pytanie ankiety. Ze względu na reprezentatywność badanej próby wyniki badania można uogólnić na całą populację biegłych rewidentów w Polsce.

Jak przedstawiono na rys. 3, na pytanie, czy stosowanie uproszczeń w sprawozdawczości finansowej przez jednostki, których sprawozdania finansowe były badane, wpłynęło na zmniejszenie liczby wykonywanych procedur badania dotyczących systemu rachunkowości, tylko niewiele ponad $9 \%$ badanych udzieliło odpowiedzi „tak”, ponad $41 \%$ ankietowanych udzieliło odpowiedzi negatywnej, 


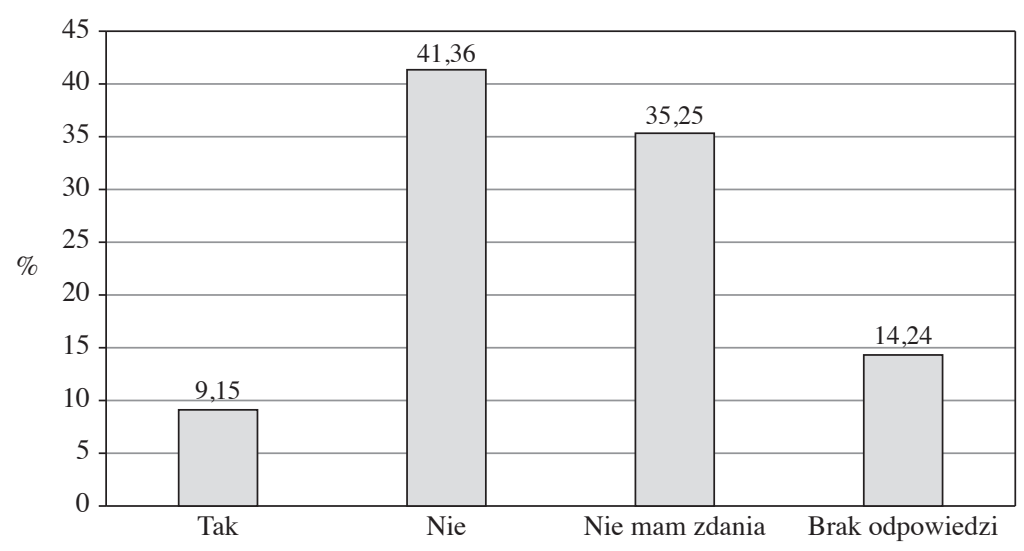

Rys. 3. Wpływ stosowania uproszczeń w sprawozdawczości finansowej na zmniejszenie liczby wykonywanych procedur badania dotyczących systemu rachunkowości (\% wskazań) Źródło: opracowanie własne na podstawie wyników badań ankietowych.

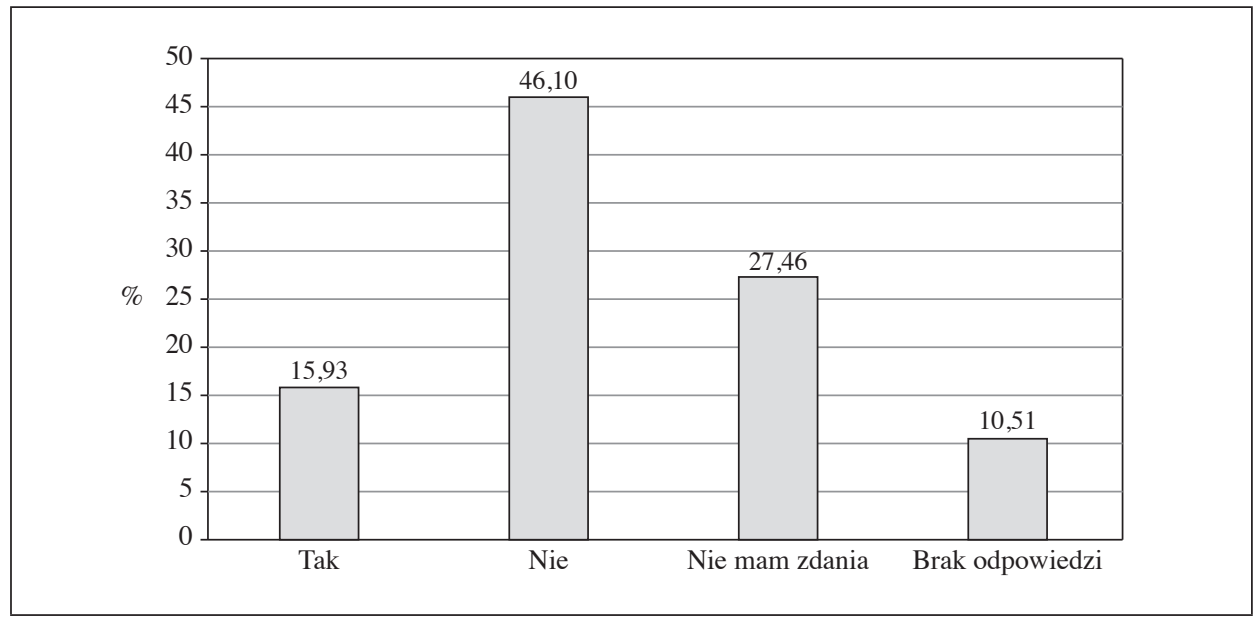

Rys. 4. Wpływ stosowania uproszczeń w sprawozdawczości finansowej na zmniejszenie zakresu wykonywanych procedur badania dotyczących systemu rachunkowości (\% wskazań) Źródło: opracowanie własne na podstawie wyników badań ankietowych.

a ponad $35 \%$ nie miało zdania w tym zakresie. Tak wysoki procent odpowiedzi negatywnych może wskazywać na to, że stosowanie zasady proporcjonalności MSB w badaniach sprawozdań finansowych w polskich warunkach nie przekłada 
się na mniejszą liczbę wykonywanych procedur badania ksiąg rachunkowych będących podstawą sporządzenia sprawozdania finansowego.

Jak wynika z rys. 4, na pytanie dotyczące wpływu stosowania uproszczeń w sprawozdawczości finansowej przez jednostki na zakres procedur badania pozostałych obszarów, takich np. jak zdolność jednostki do kontynuacji działalności czy zdarzenia po dniu bilansowym, ponad $46 \%$ ankietowanych udzieliło odpowiedzi przeczącej, a jedynie niecałe $16 \%$ twierdzącej. Mając na uwadze, że tylko niespełna $16 \%$ ankietowanych stwierdziło, że w przypadku badania uproszczonych sprawozdań finansowych zakres procedur badania jest mniejszy, ale ponad połowa uważa, że zakres ten nie uległ zmniejszeniu, oznacza to, że stosowanie skalowalności do badania uproszczonych sprawozdań finansowych sporządzanych przez jednostki mikro i małe nie powoduje zmniejszenia zakresu procedur badania. Wynika to z faktu, że jednostki sporządzające uproszczone sprawozdania finansowe są objęte takimi samymi wymaganiami dotyczącymi prowadzenia ksiąg rachunkowych jak jednostki niekorzystające z uproszczeń w sprawozdawczości finansowej oraz podlegają tym samym zasadom dotyczącym sporządzania sprawozdania finansowego, tj. przydatności i wiernej prezentacji.

\section{Podsumowanie}

Reasumując powyższe rozważania, można stwierdzić, że polski rynek badań ustawowych jednostek interesu publicznego wykazuje wysoką koncentrację, podobnie jak w innych państwach członkowskich Unii Europejskiej. Sytuacja ta wymaga ciągłego monitorowania w celu zapewnienia wysokiej jakości przeprowadzanych badań. Należy się zgodzić z R. Rydzakiem (2015, s. 70), że dominacja rynkowa określonej liczby firm audytorskich ma istotny wpływ na funkcjonowanie rynku usług audytorskich, a decyzje cenowe liderów są wzajemnie uzależnione. Cena żądana przez jednego oligopolistę w dużym stopniu wpływa na wielkości sprzedaży pozostałych. Jest to istotna bariera wejścia na rynek nowych firm audytorskich.

Wprowadzenie MSB i ich skalowalność nie przyczyniły się do zmniejszenia liczby i zakresu procedur badania uproszczonych sprawozdań finansowych, w szczególności w mikro- i małych jednostkach. Potwierdziły to wyniki ankiety przeprowadzonej wśród biegłych rewidentów. Analiza danych statystycznych wykazała natomiast, że wprowadzenie MSB w Polsce spowodowało zmniejszenie liczby biegłych rewidentów wykonujących zawód, a także liczby firm audytorskich. 


\section{Literatura}

Alwardat Y.A., Abdelhafid B. (2014), Value for Money and Audit Practice: Lessons and Facts from the Literature, „Life Science Journal”, vol. 11, nr 2.

Dyrektywa Parlamentu Europejskiego i Rady 2013/34/UE z dnia 26 czerwca 2013 r. w sprawie rocznych sprawozdań finansowych, skonsolidowanych sprawozdań finansowych i powiązanych sprawozdań niektórych rodzajów jednostek, zmieniająca dyrektywę Parlamentu Europejskiego i Rady 2006/43/WE oraz uchylająca dyrektywy Rady 78/660/EWG i 83/349/EWG, Dz. Urz. UE L 182/19 z 29.06.2013 r., https:/eur-lex. europa.eu/legal-content/PL/TXT/PDF/?uri=CELEX:32013L0034\&from=PL (data dostępu: 27.02.2020).

Dyrektywa Parlamentu Europejskiego i Rady 2014/56/UE z dnia 16 kwietnia 2014 r. zmieniająca dyrektywę 2006/43/WE w sprawie ustawowych badań rocznych sprawozdań finansowych i skonsolidowanych sprawozdań finansowych, Dz. Urz. UE L 158/196 z 27.05.2014 r., https://eur-lex.europa.eu/legal-content/PL/TXT/PDF/?uri=CELEX:32014L0056\&from=EN (data dostępu: 29.02.2020).

Eshleman J.D., Lawson B.P. (2017), Audit Market Structure and Audit Pricing, „Accounting Horizons", vol. 31(1), https://doi.org/10.2308/acch-51603.

Fałowski W. (2020), 17 lat funkcjonowania Krajowej Komisji Nadzoru, „Rachunkowość”, nr 2, https://rachunkowosc.com.pl/17_lat_funkcjonowania_krajowej_komisji_nadzoru (data dostępu: 12.02.2020).

Gad J. (2018), Rynek usług audytorskich świadczonych na rzecz spółek publicznych notowanych na polskim rynku kapitałowym, „Zeszyty Teoretyczne Rachunkowości”, t. 97(153), https://doi.org/10.5604/01.3001.0012.0353.

Iwanowicz B. (2019), Kluczowe sprawy audytu w sprawozdaniach z badania wybranych spółek giełdowych, „Zeszyty Teoretyczne Rachunkowości”, t. 105(161), https://doi. org/10.5604/01.3001.0013.6052.

KNA (2019), Sprawozdanie z monitorowania rynku usług świadczonych przez biegłych rewidentów i firmy audytorskie oraz działalności komitetów audytu, Komisja Nadzoru Audytowego, Warszawa, https://www.gov.pl/web/finanse/sprawozdania-z-monitorowania-rynku (data dostępu: 16.02.2020).

Kogut J. (2017), Kierunki zmian w systemie rewizji finansowej oraz ich wpływ na jakość i postrzeganie badania sprawozdań finansowych, ,Prace Naukowe Uniwersytetu Ekonomicznego we Wrocławiu”, nr 479, https://doi.org/10.15611/pn.2017.479.08.

Komisja Europejska (2010), Zielona Księga. Polityka badania sprawozdań finansowych: lekcje wyciągnięte z kryzysu, KOM(2010) 561, Bruksela, https://op.europa.eu/pl/publication-detail/-/publication/08744053-2f56-415a-a985-7ceaef3d3b3a/language-pl (data dostępu: 10.02.2020).

Komisja Europejska (2017), Sprawozdanie Komisji dla Rady, Europejskiego Banku Centralnego, Europejskiej Rady ds. Ryzyka Systemowego i Parlamentu Europejskiego w sprawie monitorowania zmian na rynku świadczenia usług w zakresie badań ustawowych na rzecz jednostek interesu publicznego na podstawie art. 27 rozporządzenia (UE) nr 537/2014, COM(2017) 464, Bruksela, https://eur-lex.europa.eu/legal-content/ PL/TXT/PDF/?uri=CELEX:52017DC0464\&from=PL (data dostępu: 28.02.2020).

Krajowy Standard Badania 200 w brzmieniu Międzynarodowego Standardu Badania 200, Ogólne cele niezależnego biegłego rewidenta oraz przeprowadzanie badania zgodnie z międzynarodowymi standardami badania, Załącznik nr 1.1 do uchwały 
Nr 3430/52a/2019 Krajowej Rady Biegłych Rewidentów z dnia 21 marca 2019 r., https://www.pibr.org.pl/assets/file/4169,1.1\%20KSB\%20200.pdf (data dostępu: 28.02.2020).

KRBR (2015a), Uchwała nr 2783/52/2015 Krajowej Rady Biegłych Rewidentów z dnia 10 lutego 2015 r. w sprawie krajowych standardów rewizji finansowej, https://www. pibr.org.pl/pl/uchwaly-krbr\#krajowe-standardy-wykonywania-zawodu (data dostępu: 29.02.2020).

KRBR (2015b), Uchwała nr 2784/52/2015 Krajowej Rady Biegłych Rewidentów z dnia 10 lutego 2015 r. w sprawie zasad wewnętrznej kontroli jakości w podmiocie uprawnionym do badania sprawozdań finansowych, https://www.pibr.org.pl/assets/ file/365,KRBR-uchwala-2784-52-2015.pdf (data dostępu: 28.02.2020).

KRBR (2017), Uchwała nr 913/22a/2017 Krajowej Rady Biegłych Rewidentów z dnia 24 stycznia 2017 r. zmieniająca uchwałę w sprawie krajowych standardów rewizji finansowej, https://www.pibr.org.pl/pl/uchwaly-krbr\#krajowe-standardy-wykonywania-zawodu (data dostępu: 28.02.2020).

Kucharczyk K. (2018), Duże przetasowania na krajowym rynku audytu, Parkiet, https:// www.parkiet.com/Firmy/312089988-Duze-przetasowania-na-krajowym-rynkuaudytu.html (data dostępu: 16.02.2020).

Piekarska L. (2008), Globalny kryzys finansowy, http://kolegia.sgh.waw.pl/pl/KES/struktura/kue/publikacje/Documents/Piekarska\%20-\%20GLOBALNY\%20KRYZYS\%20 FINANSOWY\%20Z\%202008\%20R.pdf (data dostępu: 10.02.2020).

Przewodnik stosowania Międzynarodowych Standardów Rewizji Finansowej w badaniu małych i średnich jednostek (2013), tłum. A. Barcikowska, E. Sobińska, J. Zakrzewska, wyd. 3, IFAC, KIBR, Warszawa.

Rada dyrektorów Izby Biegłych Rewidentów (Wirtschaftsprüferkammer): Uwagi odnośnie podejścia proporcjonalnego (skalowanego) do wykonania badania na podstawie MSB (2015), https://www.pibr.org.pl/pl/aktualnosci/5,Wykonywanie-badania-na-podstawieMSB-dokument-WPK (data dostępu: 16.02.2020).

Rozporządzenie Parlamentu Europejskiego i Rady (UE) nr 537/2014 z dnia 16 kwietnia 2014 r. w sprawie szczegółowych wymogów dotyczących ustawowych badań sprawozdań finansowych jednostek interesu publicznego, uchylające decyzję Komisji 2005/909/WE, https:/op.europa.eu/pl/publication-detail/-/publication/567809be-e656-11e3-8cd4-01aa75ed71a1 (data dostępu: 28.02.2020).

Rydzak R. (2015), Rewizja finansowa jako element systemu zapewnienia bezpieczeństwa obrotu gospodarczego - wybrane problemy (w:) Zarzqdzanie ryzykiem w gospodarce, red. K. Raczkowski, S. Wojciechowska-Filipek, Wydawnictwo Społecznej Akademii Nauk „Przedsiębiorczość i Zarządzanie”, t. XVI, z. 8, cz. III.

Rynek audytu w Polsce: kluczowe dane statystyczne i postrzeganie rynku (2016), Word Bank Group, Centre for Financial Reporting Reform (CFRR) Governance Global Practice, http://www.wordbank.org/en/publication/Raport_Rynek-audytu-w-Polsce_2016.pdf (data dostępu: 10.02.2020).

Staszkiewicz P. (2017), Quo vadis, auditor? Synteza badań nad rewizja finansowa w polskiej domenie publicznej, ,Zeszyty Teoretyczne Rachunkowości”, t. 95(151), https:// doi/org/10.5604/01.3001.0010.6568.

Szczepankiewicz E.I. (2011a), After the Crisis? The New (?) Role and Taks of the Internal Audit and Audit Committee as Bodies Supporting Effective Corporate Governance in Financial Institutions in Poland (w:) Contenporary Issues in Economy: After 
the Crisis, A.P. Balcerzak (ed.), International Conference 13-14 May 2011, Nicolaus Copernikus University, Torun.

Szczepankiewicz E.I. (2011b), The Role of the Audit Committee, The Internal Auditor and the Statutory Auditor as the Bodies Supporting Effective Corporate Governance in Banks, „Zeszyty Naukowe Uniwersytetu Szczecińskiego nr 640. Finanse, Rynki Finansowe, Ubezpieczenia", nr 38, http://www.wneiz.pl/nauka_wneiz/frfu/38-2011/ FRFU-38-885.pdf (data dostępu: 28.11.2017).

Szczepankiewicz E.I. (2011c), Selected Issues in Effective Implementation of the Integrated Risk Management System in an Organization, ,Zeszyty Naukowe Uniwersytetu Szczecińskiego 688. Finanse, Rynki Finansowe, Ubezpieczenia”, nr 49, http://www. wneiz.pl/nauka_wneiz/frfu/49-2011/FRFU-49-153.pdf (data dostępu: 28.11.2017).

Szczepankiewicz E.I. (2012a), New Regulations and Internal Control System as Supporting Effective Corporate Governance in Commercial Banks in Poland (w:) Banking and Financial Markets. After Global Crisis of the Years 2008-2010, A.P. Balcerzak (ed.), Nicolaus Copernikus University, Toruń.

Szczepankiewicz E.I. (2012b), The Role and Tasks of the Internal Audit and Audit Committee as Bodies Supporting Effective Corporate Governance in Insurance Sector Institutions in Poland, „Oeconomia Copernicana”, nr 4, http://economic-research.pl/ Journals/index.php/oc/article/view/456/420, https://doi.org/10.12775/OeC.2012.021 (data dostępu: 28.11.2017).

Ustawa z dnia 19 października 1991 r. o badaniu i ogłaszaniu sprawozdań finansowych oraz biegłych rewidentach i ich samorządzie, Dz.U. nr 111, poz. 480.

Ustawa z dnia 29 września 1994 r. o rachunkowości, tekst jednolity Dz.U. 2019, poz. 351 z późn. zm., http://prawo.sejm.gov.pl/isap.nsf/download.xsp/WDU19941210591/U/ D19940591Lj.pdf (data dostępu: 28.02.2020).

Ustawa z dnia 13 października 1994 r. o biegłych rewidentach i ich samorządzie, Dz.U. nr 121, poz. 592.

Ustawa z dnia 21 września 2000 r. o biegłych rewidentach i ich samorządzie, Dz.U. nr 89, poz. 992.

Ustawa z dnia 29 lipca 2005 r. o obrocie instrumentami finansowymi, tekst jednolity Dz.U. 2020, poz. 89.

Ustawa z dnia 7 maja 2009 r. o biegłych rewidentach i ich samorządzie, podmiotach uprawnionych do badania sprawozdań finansowych oraz o nadzorze publicznym, Dz.U. nr 77, poz. 649.

Ustawa z dnia 11 maja 2017 r. o biegłych rewidentach, firmach audytorskich oraz nadzorze publicznym, Dz.U. 2017, poz. 1089 z późn. zm., http://prawo.sejm.gov.pl/isap.nsf/download.xsp/WDU20170001089/T/D20171089L.pdf (data dostępu: 12.02.2020).

Ustawa z dnia 6 marca 2018 r. Prawo przedsiębiorców, Dz.U. 2018, poz. 646 z późn. zm., http://prawo.sejm.gov.pl/isap.nsf/download.xsp/WDU20180000646/U/D20180646Lj. pdf (data dostępu: 28.02.2020).

Ustawa z dnia 19 lipca 2019 r. o zmianie ustawy o biegłych rewidentach, firmach audytorskich oraz nadzorze publicznym oraz niektórych innych ustaw, Dz.U. 2019, poz. 1571, http://prawo.sejm.gov.pl/isap.nsf/DocDetails.xsp?id=WDU20190001571 (data dostępu: 28.02.2020). 


\section{The Introduction of International Audit Standards in Poland and Its Impact on Audit Firms and Procedures (Abstract)}

Objective: The study seeks to determine the impact of introducing the mandatory application of the International Audit Standards (IAS) to the audit market in Poland and the scope of procedures in the auditing of simplified financial statements.

Research Design \& Methods: To achieve the objective, the following are used: analysis of the literature, legal acts, and empirical evidence received from surveys and statistics.

Findings: The study showed that the mandatory introduction of IAS in Poland led to a decrease in the number of statutory auditors and audit firms, but no corresponding decrease in the scope of audit procedures of simplified financial statements.

Implications/Recommendations: Analysis of surveys has shown that simplifications made to financial reporting do not reduce the scope of the audit procedures despite the scalability of IAS.

Contribution: Beyond the present work, no studies on the impact of IAS on the auditing of simplified financial statements have been done. However, the present work allows for the conclusion that the scope of procedures are not reduced and they are useful for assessing the simplifications used and changes in the audit market.

Keywords: audit, audit firm, International Audit Standards, International Standard on Assurance Services, KSB, MSB, audit market. 